Azizi Bahauddin, et al., Int. J. of Design \& Nature and Ecodynamics. Vol. 8, No. 4 (2013) 311-324

\title{
THE MINANGKABAU HOUSE - A VISION OF SUSTAINABLE CULTURE AND ARCHITECTURE
}

\author{
AZIZI BAHAUDDIN, SETIAWAN HARDONO, ALDRIN ABDULLAH \& NOR ZARIFAH MALIKI \\ School of Housing, Building and Planning, Universiti Sains, Malaysia.
}

\begin{abstract}
The grandeur of the Minangkabau house in Western Sumatera, Indonesia, can be observed in its multi-tiered curved roof structure with upswept gables to mimic the horn of the buffalo. Associated with the Minangkabau people, the strong cultural influence of the people is further reflected in the internal layout of the house and other demonstrations of architectural elements that are echoing nature. Many claim that this is a result of the influence of the matriarch who governs the community along with her matrilineal line. It is a rationale for discussions on sustainable cultural and architectural influences. This paper further analyses the family system in relation to this architecture. The research aims to analyse the matrilineal influence on the architecture and its sustainable and cultural issues. The methods employed include the ethnography and phenomenology processes supported by field research in villages in Western Sumatera. Ultimately, the Minangkabau traditional architecture represents a house that visualises the dwellers' matrilineal culture.

Keywords: Matriarch, matrilineal system, minangkabau house, sustainable.
\end{abstract}

\section{INTRODUCTION}

Culture plays a major role in shaping the uniqueness and aesthetics in architectural elements of traditional homes [1]. The traditional architecture can be explained by the study of related culture as both are interrelated [2]. Its architectural components are seen to be able to produce sustainable design in harmony with the environment [3]. Hence, traditional architecture should be preserved due to the high aesthetic values that can be inherited by the present generation and generations to come [4]. The Minangkabau society is well known for its traditional and cultural home. The Minangkabau culture has existed since around $500 \mathrm{AD}$. The community and culture began in some areas of Western Sumatera (Fig. 1) known as Wilayah Nan Tiga consists of Luhak Tanah Datar as the first region, Luhak Agam as the second region and Luhak Lima Puluh Kota as the newest province [5-9].

Pagarruyung in Tanah Datar was designated as the Minangkabau Government Centre [2] and led by a king known as Rajo Alam [10]. The Minangkabau kingdom's glory and success have made it one of the few famous kingdoms throughout the Malay Archipelago [11]. The Minangkabau house is also known as the ceremonial house as well as a place of residence. It was used as a symbol of a people, and to hold a variety of rituals, customs and family activities [2, 5, 6, 8]. The physical shape is easily recognised because for its multi-tiered concave roof (Figs $2 \& 3$ ) and this is not seen on other traditional houses [2].

The concept of 'alam takambang jadi guru' or nature as a guide is the foundation of the Minangkabau culture. It is capable of sustaining the culture embedded in the architecture that is compatible with the environment. The environment has become a source of natural science to the community. The Minangkabau society adheres very strongly to nature as a guide [12]. The interior layout reflects the customs and the occupants' behaviour [6]. The architectural uniqueness and greatness exist through the concept and philosophy of the community that is based strongly on the matrilineal society [9]. This matrilineal society is descended from hundreds of years ago [13-16]. Such unique custom thus reflects in the appearance of the interior layout of the house and it is able to create harmonious relationships and integration to the house occupants [6].

(C) 2013 WIT Press, www.witpress.com

ISSN: 1755-7437 (paper format), ISSN: 1755-7445 (online), http://journals.witpress.com

DOI: 10.2495/DNE-V8-N4-311-324 


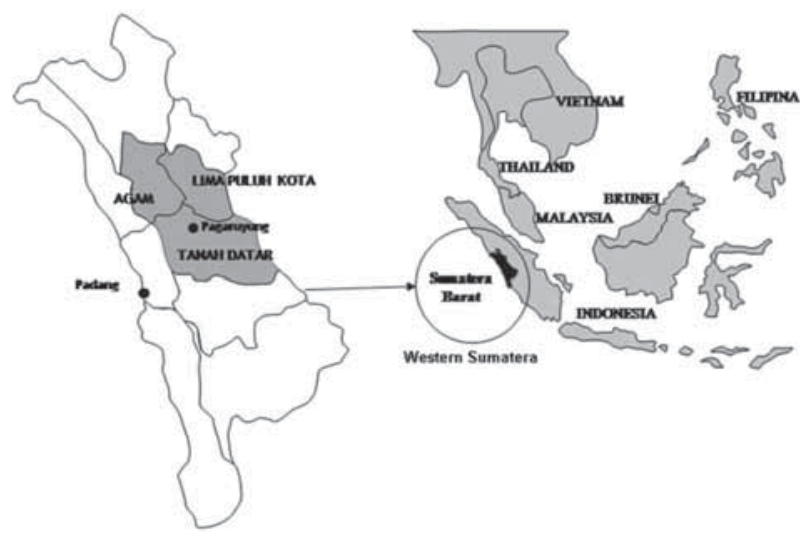

Figure 1: Location map of Wilayah Nan Tiga Minangkabau, Western Sumatera in Southeast Asia.

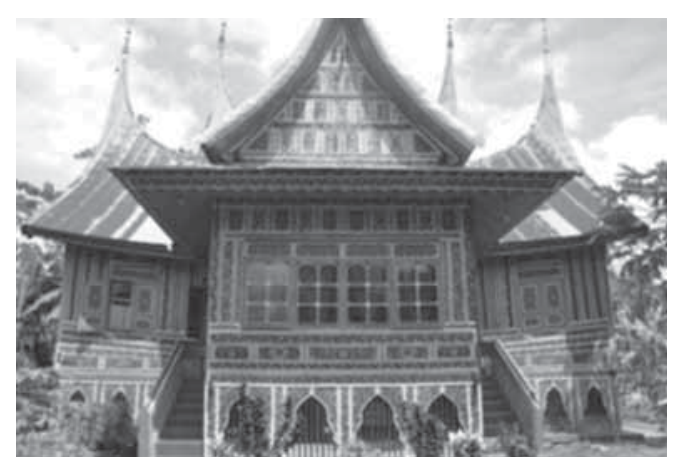

Figure 2: Datuk Paduko Alam house Nan In Lintau Buo, Tanah Datar.

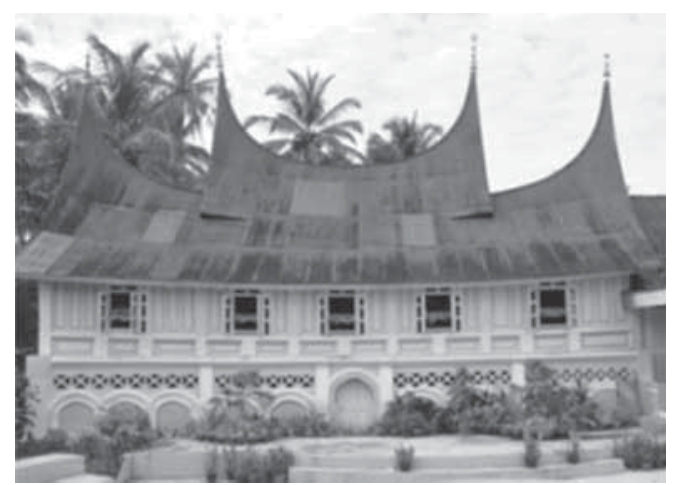

Figure 3: Datuk Rajo Mangkuto Putih in Payakumbuh, Lima Puluh Kota. 


\section{OBJECTIVES AND METHODOLOGY}

Physical characteristics of the ceremonial house are formed through the customs and cultural practices of a strong community. Therefore, this study was undertaken to analyse the effect on the sustainability of matrilineal elements of culture and architecture of the Minangkabau house in Western Sumatera. The study used references from previous research as the initial information. This research was done through field studies involving the phenomenology, case study and ethnography methods. To find the answer to this study, any relationship between customary activities with the formation of the architectural elements in particular on the layout and custom home interior circulation was investigated. This study involved the traditional Minangkabau villages in Western Sumatera. Some Minangkabau houses were selected to serve as case studies.

Case study method is done through cross referencing with the goals and objectives of the research that investigated into the background of individuals and community groups to establish social connections with the architecture [17]. Visual data in the form of photographs and measured drawings were collected and documented. Interviews and observation processes were conducted simultaneously along with the visual data collection for information obtained would interpret designs created in the architecture. This method is consistent with the study design outlined by Mat [18] stating that the shape, size and house internal circulation should be documented in the form of working drawings and followed up with interviews and observations to verify information in various angles. The matrilineal influence on cultural sustainability and the ceremonial house would be further explained through interviews and observational process. Based on the observations, there were a total of 44 ceremonial houses (Table 1) identified.

These houses were located in the areas of Luhak Tanah Datar, Luhak Agam and Payakumbuh. However, only a few of the houses were selected. They were chosen due to their close resemblance to the authentic forms of Minangkabau house stated by the Minangkabau people. Ceremonial houses in these areas are divided into several types according to the levels. Surveys on houses that have been selected as case studies were carried out simultaneously under the phenomenological and

Table 1: Identified ceremonial houses.

\begin{tabular}{cllcc}
\hline No. & \multicolumn{1}{c}{ District } & \multicolumn{1}{c}{ Luhak } & No. & Total \\
\hline 1. & Lintau Buo & Tanah Datar & 7 & \\
2. & Tabik Baso, Batu Sangkar & Tanah Datar & 2 & \\
3. & Koto Tuo, Batu Sangkar & Tanah Datar & 2 & \\
4. & Gudam Pagaruyung, Batu Sangkar & Tanah Datar & 3 & \\
5. & Rao Rao, Batu Sangkar & Tanah Datar & 2 & \\
6. & Sungayang & Tanah Datar & 4 & 44 \\
7. & Tanjung Alam & Tanah Datar & 1 & \\
8. & Padang Taro, Bukittingi & Agam & 6 & \\
9. & Piaro Alam, Bukittinggi & Agam & 2 & \\
10. & Koto Selayan, Bukittinggi & Agam & 1 & \\
11. & Koto Nan Gadang, Paya Kumbuh & Lima Puluh Kota & 8 & \\
12. & Koto Nan Ampek, Payakumbuh & Lima Puluh Kota & 3 & \\
13. & Paya Kumbuh & Lima Puluh Kota & 2 & \\
14. & Paya Kumbuh Timur & Lima Puluh Kota & 1 & \\
\hline
\end{tabular}


ethnographical research methods on culture and customs that serve as study variables requiring the researcher to be in the community for a long time [19].

\section{THE MINANGKABAU CULTURE}

Customs and Islam are two important components in the Minangkabau culture seen as both complementing each other. The phrase 'the custom is governed by Islamic rules and the Islamic rules are governed by the Koranic teachings' gives a very clear indication that the Minangkabau customs are steeped in the Islamic teachings, as these teachings were written in the Koran and Hadith (the words of the Prophet Muhammad); and they must be adhered to. The Minangkabau society in the Malay Archipelago is known for its spiritual loyalty to Islam and holding fast to the faith. In the 14th century, the Minangkabau people received the advent of Islam and believed that Islam complements the culture $[9,13]$. Components of this culture have been the core of life of the Minangkabau for years, a departure from the animistic beliefs [13]. Hence, the custom of the culture encompasses a very broad sense as it includes regulations that guide the community to achieve happiness and success in both religious and non-religious affairs [20]. Customary rules and principles were established in the community through cultural philosophy. The concept of 'alam takambang jadi guru' has become the dominant philosophy in the Minangkabau culture [9, 19]. In this concept, nature and human beings are interdependent and part of the environment created by the Almighty. Hence, the universe is used as a guide to educate the people through mutual respect, love and exist in harmony with the environment [13].

Customary laws and regulations in the Minangkabau culture are divided into four stages. Each level has a different law. The first stage is called 'the definite custom,' the second is 'the created custom,' the third is 'a customary tradition,' and the fourth is 'the rites' $[11,13,15]$. Each level has a basic role and functions involving customs that either can or cannot be changed. An unchangeable custom is a custom based on the Islamic faith, and the law of nature mentioned as 'the definite custom' and 'the created custom'; whereas changeable customs are 'the customary tradition' and 'the rites.' These changeable customs can be modified to suit the local community agreed upon through discussions guided by a set of rules and laws. This culture is divided into two systems of governance. The Koto Piliang was led by Datuk Ketemenggungan, an autocratic custom, whereas the Bodi Caniago was led by Datuk Perpatih, a democratic custom $[6,8,11]$. However, they both still practiced the same matrilineal kinship in which women would be given the privileges to accede to the lineage, inheritance and the rights to voice opinions.

\section{THE MATRILINEAL KINSHIP}

The Minangkabau community in Western Sumatera is the largest community in the world who adheres to matrilineal kinship [21]. The clan is classified as the fourth largest tribe in Indonesia and the only people who practice the matrilineal custom in this country. Through this tradition, women are given the privilege to inherit the lineage and inheritance. The women were also given special positions with the title bundo kanduang (the matriarch) [5]. The title is very befitting describing the characteristics of a good leadership and a planner [22]. Although the maternal brother or known as mamak leads only in the customary ceremonies [5]. In contrast, the men are only the fathers to their children or husbands to wives and are only considered as outsiders or given title as urang sumando $[15,23]$. They are not given the right to inherit [24]. In general, bundo kanduang (matriarch) can control the economy by keeping the inherited estate, and being a wife and mother who can maintain a family custom and religion $[22,25]$. Women have very big function in the society as expressed through their family lineage [5]. In addition, they are also the strength of the community and supporters to the men. The wisdom possessed by women would be able to make them better leaders of 


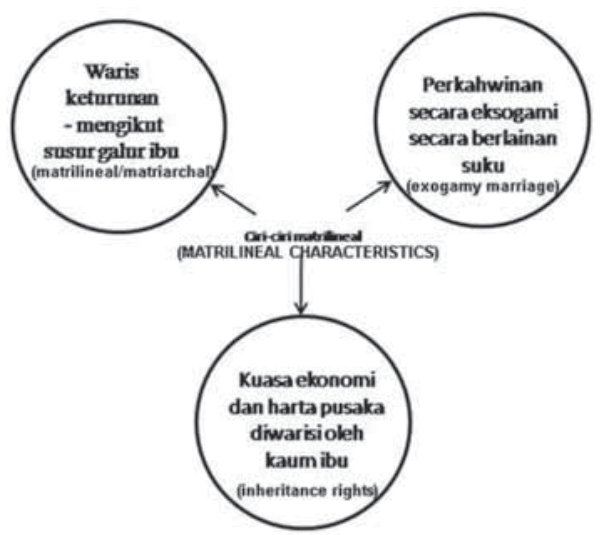

Figure 4: Characteristics of matrilineal kinship, Adapted from Amir [20].

the community thus making the view of bundo kanduang (matriarch) important in a community's decision-making processes [22].

There are three characteristics of the matrilineal kinship system that are the strength of the community in keeping the culture alive (Fig. 4). The title of a powerful mother or bundo kanduang is matriarchal whereas the term for the descendants or followers of the custom is known as matrilineal and still going strong to this day [20]. The well-managed administrative, social and economic systems cover all aspects of life, including the area of designing and constructing the ceremonial house. The circulation in the house is designed according to the comfort of the women [14]. This can be explained when all daughters are given the rights to their own rooms and when newly married daughters will be given a special treatment.

\section{THE MINANGKABAU CEREMONIAL HOUSE}

The traditional house in the Minangkabau society is known as the ceremonial house because apart from being a place of residence, it is also used as a venue for cultural ceremonies for the family or community $[6,5]$. The house has become a symbol of glory and the existence of a community $[5,9,26]$. The construction is not simply to be owned by an individual but for the community. Therefore, all individuals in the same community have the right to use the ceremonial house to conduct ceremonies such as marriage, appointing leaders, coming of age, funerals, etc. [6]. This house is inhabited by a large family (extended family), which can consist of several generations. Families residing in this house would be of three to four generations of mother to the grandmother, the grandmother, the mother's family and the daughter. In general, the ceremonial house is occupied only by the maternal descendent, and led by a brother of the mother. The leader is called mamak tungganai that carries the title Datuk or Your Excellency $[2,26]$.

In addition to mamak tungganai (leader) each ceremonial house has a bundo kanduang (matriarch) with the title of limpapeh nan gadang or the beautifier and a protector. Her function is as the leader to the community and to other women (who have married daughters with children), and manages all matters related to the family in the house. Until now, the house is still in use and has been passed on to the mothers and daughters for generations. It is considered as one of the unique characteristics in the matrilineal system when mothers and daughters possess the right to inherit properties, including the ceremonial house. It has become the pride of the community because the architecture is rich with cultural values based on the matrilineal kinship. Therefore, based on the customary law, the house 
cannot be traded because it is considered to be the property of valuable inheritance bequeathed by the ancestors over time [6,9]. In addition, the beneficiaries must also have the characteristics of individuals who adhere to the customs and qualify to inherit the house according to the law [6].

In general, there are two types of ceremonial house [5-9]. The ceremonial house design with verandas was established by the community with the Koto Piliang influence, whereas the ceremonial house without verandas was by the community of Bodi Caniago [6]. A large number of ceremonial houses with verandas are situated in the area of Luhak Tanah Datar whereas the ceremonial houses without verandas are mostly found in the Luhak Agam and Luhak Lima Puluh Kota [5-9]. The significant differences in these two types of houses can be seen in the number of internal floor spaces. The Koto Piliang ceremonial house has verandas and a high floor, and the Bodi Caniago house is the opposite (Fig. 5). These differences exist through the result of the system of governances practiced by both leaders. The Koto Piliang practices principles that distinguish levels of autocracy of leaders reflected in the multilevels of floors. The Bodi Caniago ceremonial house is without verandas and influenced by the democratic principles. However, the layout of the interior space and the physical form of these ceremonial houses has more similarities than differences.

The house design is rectangular and elongated, and the interior layout is divided into three areas, namely the space at the front, the middle part as the main space and the space at the back. The kitchen area was prepared in accordance with the requirements and is outside the house. The interior layout is divided into lanja or bays and spaces (Fig. 6). Specifically the distance from the front to the
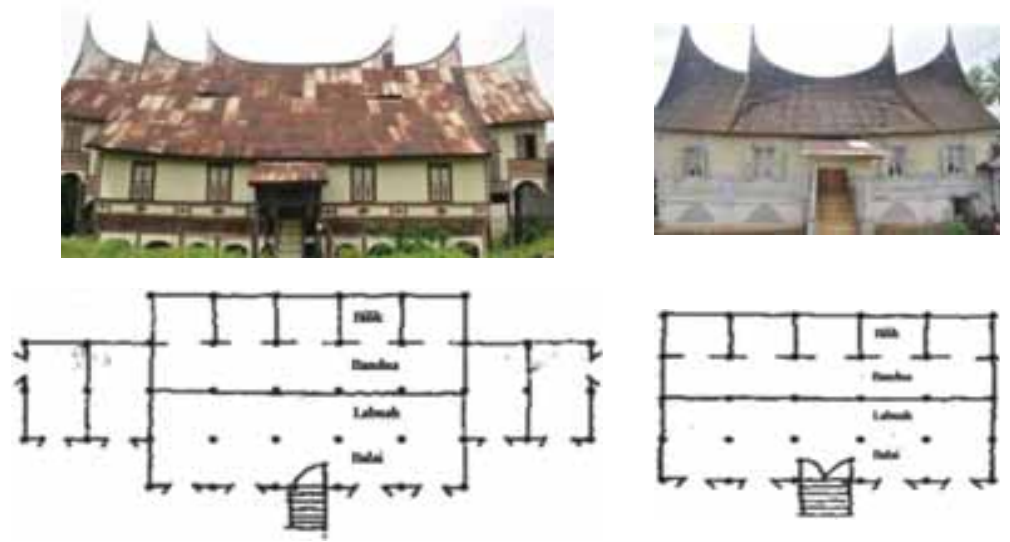

Figure 5: Differences between ceremonial house with and without anjung (verandas).

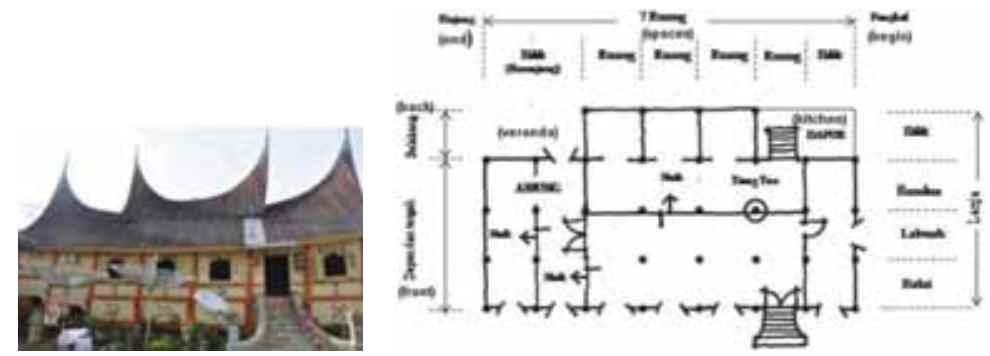

Figure 6: Floor plan of Datuk Rajo Mantro Alam house, Nagari Koto Nan Ampek, Payakumbuh, Lima Puluh Kota. 
back room is known as a lanja or a bay and the distance from the right side to the left side is known as a ruang or space [5]. The space on the right side is known as the beginning, whereas the space on the left side is known as the ending. The lanja is divided into four bays known as the lanja/bilik (room), bandua (ante room), labuah (open space) and balai (foyer). The floor height of the lanjal bilik (room) is the same as the lanja bandua (ante room) but higher than tanja labuah (open space) and balai (foyer) (Fig. 7). This floor is raised $20 \mathrm{~cm}$ and is known as the tingkah or level. In Koto Piliang style, the verandas will be at the tip either of the left or right side of the base, or on both sides. The anjung (veranda) is raised higher than the lanja bandua (ante room) (Fig. 8).

The layout of the house is made of indoor and outdoor spaces (Fig. 9). It has separate spaces for men and women. This separation of spaces remains a priority in the matrilineal custom requiring women to be protected and respected especially for the dignity of the bundo kanduang (matriarch) [6]. Spaces in the house are divided into front or middle space, and back. The front room or centre space is an open area consisting of the lanja balai (foyer), labuah (open space), bandua (ante room) and used as a main space for carrying out community meetings [5]. The back space is an enclosed area consisting of the lanja bilik (room) reserved for married daughters. In general, the room at the back or at the side of the space are private and not everyone is allowed to enter. The interior layout of the house is divided into three, namely private, semi-private and public spaces [5,6]. Such spatial distributions indirectly divide these spaces for individual, family and community activities either for daily chores or during a celebration.

The lanja bilik (room) at the back is used to provide shelter to the women and their husbands the urang sumando as well as their children. This space is categorised as private and used only for

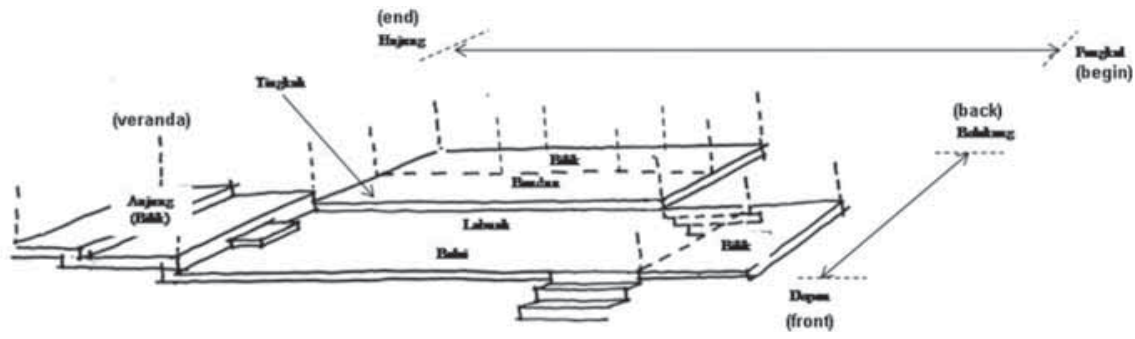

Figure 7: The different heights of floors.

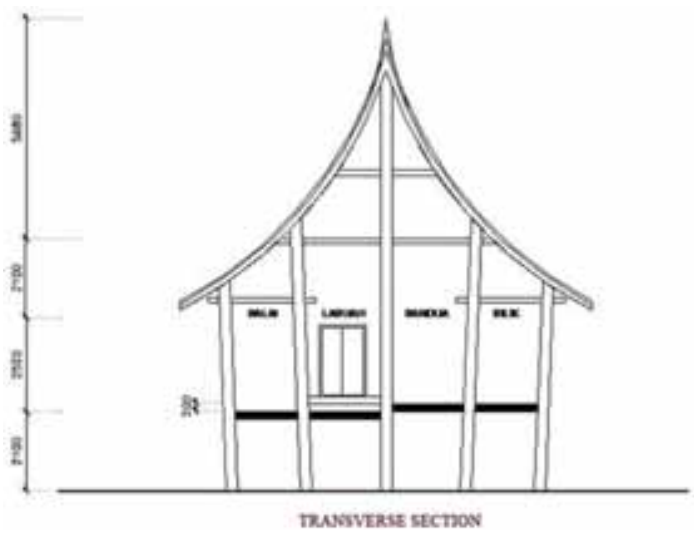

Figure 8: Transverse section. 


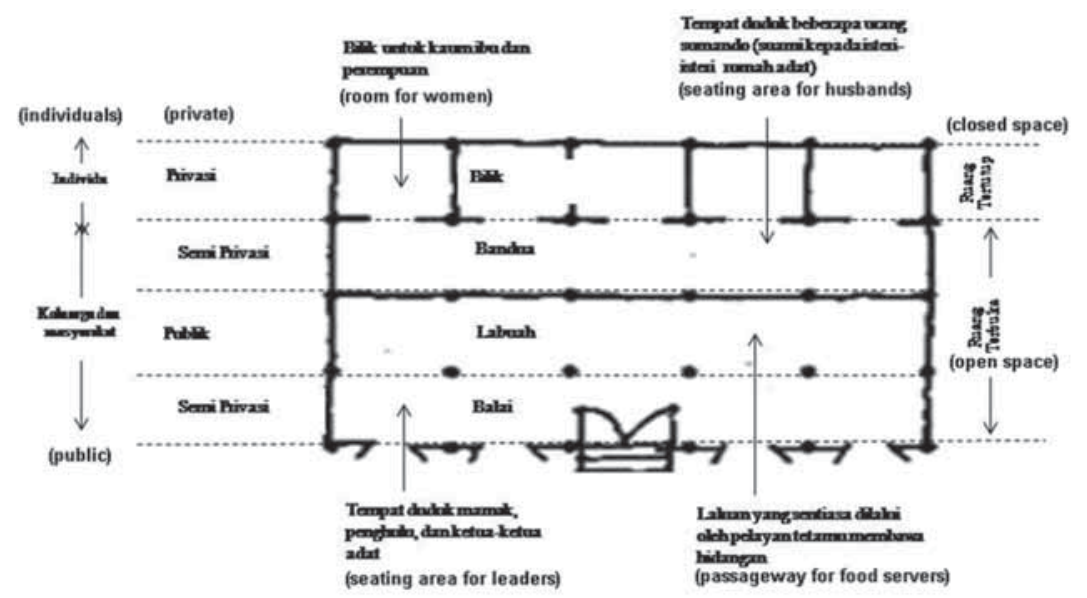

Figure 9: Distribution function concept and interior space layout.

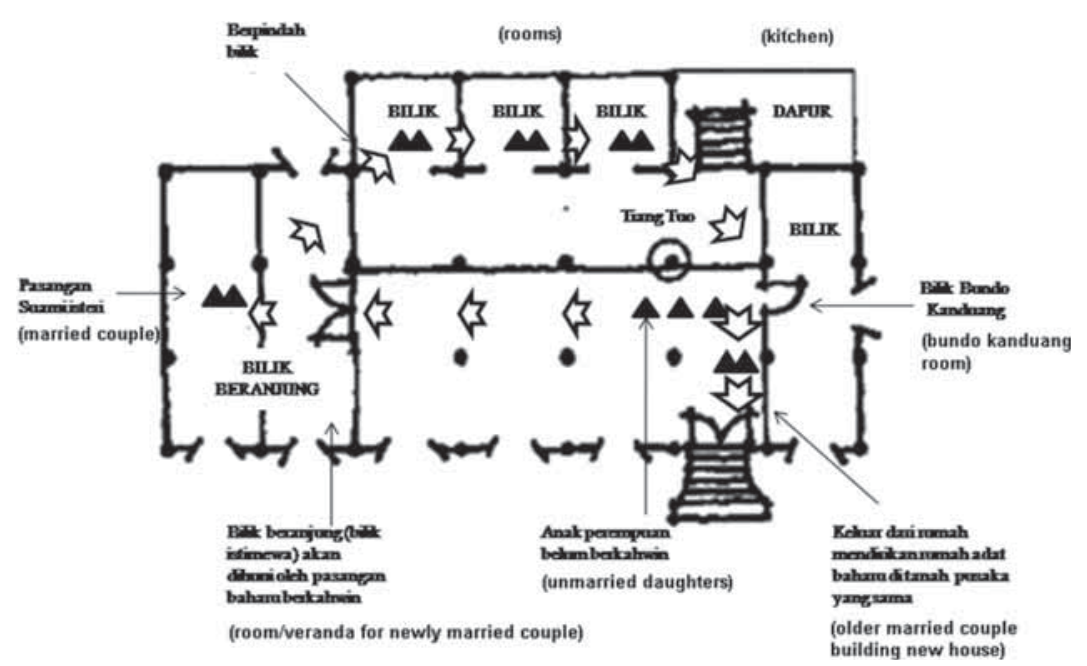

Figure 10: Space circulations for married daughters.

individual activities, whereas the lanja balai (foyer), labuah (open space) and bandua (ante room) are used as family and communal activity spaces. The lanja bandua (ante room) and lanja balai (foyer) are semi-private spaces because these spaces are used as the seating area of the family for several urang sumando - husbands and women, the mamak (brother of the mother's side) the leader of the community and the leaders for performing rituals [6]. The lanja bandua (ante room) also serves as a waiting area for the house occupants. The lanja balai (foyer) serves as a seating area for the male guests during rituals and is known as the honourable chamber. The lanja labuah (open space) is also a public space being a circulation area for the food servers during ceremonies. This layout proves to give comfort in concordance with the family and the community. Thus, during a ceremony, each individual in attendance is aware of his/her position in the house. In this house, a married daughter is given a privilege to have a room [5, 14]. Newly married couples are given privacy and have special rooms at the house end (Fig. 10). If there is a new pair of married couples, the 
couples who got married earlier will move to the middle room. The process continues until there is no room left for the old couples triggering the need to build a new home. The internal circulation is designed and laid out to provide comfort and security to occupants [14, 24]. The verandas are used as seating areas for honoured guests such as the community and ritual leaders. The veranda space at times is also used as a bedroom for the newly married daughter with a more private location. The floor is raised both on the right and left ends.

\section{SUSTAINABLE CULTURE AND ARCHITECTURE}

The architectural features of the ceremonial house stem from the values of society adhering to the customs and culture [6]. The culture is reflected in the architecture centred on rituals, philosophy and old beliefs $[9,26]$. The architectural components have been introduced according to functions, cultural and architectural that can provide harmony and comfort to individuals, families and communities. Thus, the cultural sustainability of the architecture has remained and is still passed down to today's generation. It cannot be denied that when constructing this type of house, it is perceived as one of very unique cultural heritage of architectural importance derived from cultural elements such as from the matrilineal system. It is made stronger with the influence of a tribal society, lineage, ethnicity and maternal authority, and the inheritance of the estate. The elements of this culture have been embedded from the early stages of the construction of the house until it is in use. This clearly shows that the philosophical and cultural traditions in using the universe as a guide is to direct the community towards the right way of life or to celebrate ritualistic ceremonies in a comfortable and harmonious situation, housed by the traditional architecture environment and culture in view of their sustainable conditions. The cultural philosophy of nature was manifested in the house through the vagaries of decorative carvings on the walls, ventilation systems and natural lighting systems. Its walls are decorated with carvings and quirks of nature such as plants that symbolise the nature of the Minangkabau cultural philosophy.

Sustainability, cultural and architectural characteristics can be seen at the beginning of the house construction. Tukang tuo or a skilled constructor and bundo kanduang (matriarch) would take a few days to determine the appropriate site. The determination of this site based on the elements of rituals and customs and cultural beliefs has been passed on through generations. Problematic sites will be abandoned due to the beliefs that the residents and family may encounter domestic problems if still living at the site, for the Minangkabau people still strongly believe in the existence of supernatural elements [5]. In practice, the determination of a location to build a house requires investigation before the construction work can take place. This belief is in line with the safety of the occupants as practised in the sustainable architecture and environment. It demonstrates that the sustainability of the architecture and culture go hand in hand so as to guide the harmony and well-being of the community. The Minangkabau culture cannot be separated from the ceremonial house. The body size measurements of bundo kanduang (matriarch) will be used to build the house. This is in view of the importance of the main occupant of the house, the owner and heir, who spends her life in the house. Positions of her standing, sitting and lying down will determine the house comfort scales such as for windows, doors and floor heights in the house. The window height is based on a woman of adult height sitting in a cross-legged position, in a position to look out into the surroundings [5].

Based on the requirements of the ventilation system and lighting, the house used nature as an element of energy. Air and light vents were designed on the walls of the building. Shapes were carved with motifs from nature such as plants (Fig. 11) and geometry (Fig. 12). The people believe that nature can give peace to humans. Moreover, natural elements such as sunlight and ventilation can have a big impact on energy saving in a traditional house [3]. The people build a house based on the configuration of a human body where the roof is assumed as the head, the body as the wall and the 

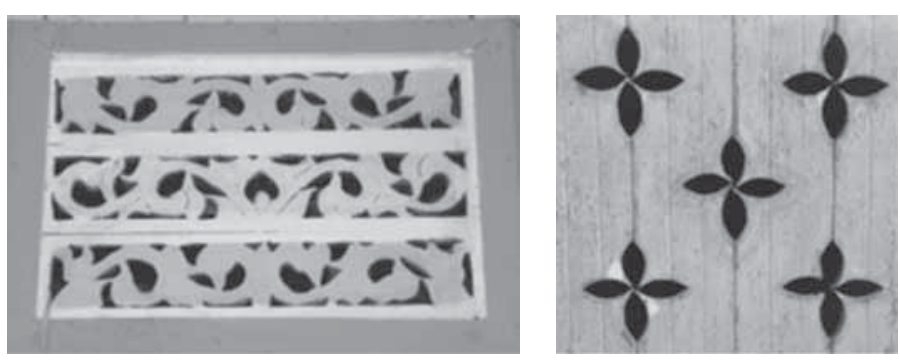

Figure 11: Air and light vents carved with motifs.

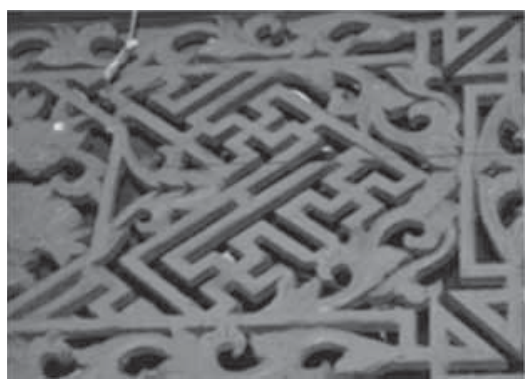

Figure 12: Carved plant geometrical motifs.
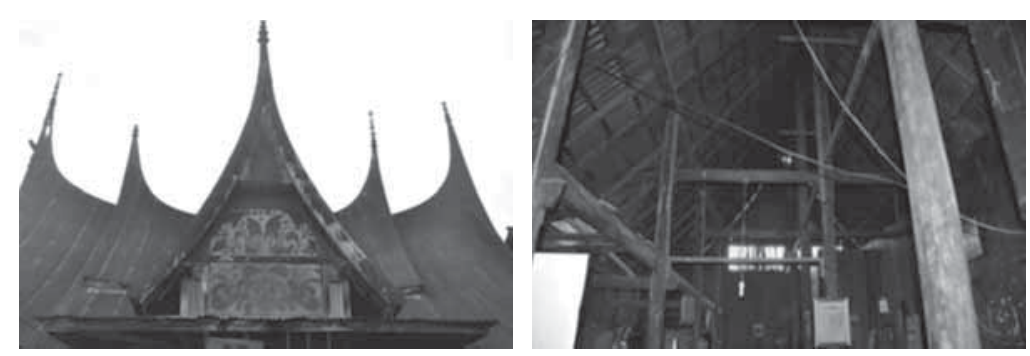

Figure 13: The curved roof provides ventilation and facilitate the flow of rain water.

pillars as legs [2]. Therefore, all of these elements have important functions in the house. Overall these elements have a cultural philosophy in turning a house into a sustainable building.

A high curved sloping roof structure (Fig. 13) is not only designed to provide cool ventilation in the house, but the roof being taper-shaped is capable of draining rain water with appropriate speed throughout the year. Initially, the material used to make the roof is of $i j u k$ or palm fronds that are able to allow cool natural air into the house but now the roof material is made of zinc. The roof over the staircase can provide shade from the sun in hot season and cover during the rainy season.

The column of the house is assumed to be part of the foot and the first architectural component to be erected in a house construction. These columns (Fig. 14) have names and functions are given; and among them are the tiang tepi - side columns, tiang tangah - middle columns, tiang panjang - long columns, tiang dalam - inside columns and tiang salek - the back columns. There are also two additional types of column. They are tiang temban - the intermediate columns, and tiang anjung columns for verandas in the Koto Piliang house. There is also a column called tiang tuo - the main 


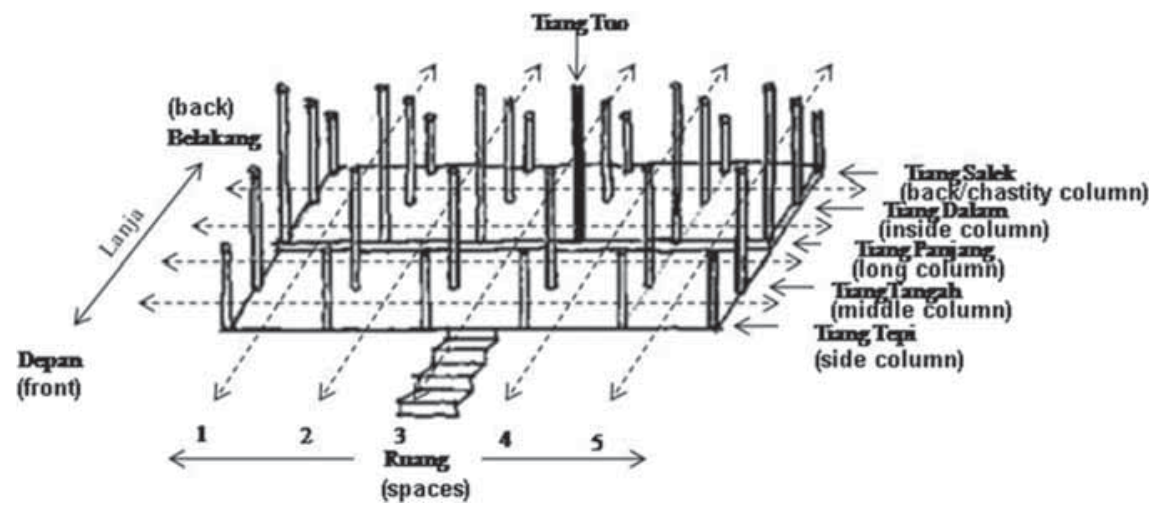

Figure 14: Column positions for five-spaced ceremonial house.

column. According to the custom and ritual beliefs, the tiang tuo must be mounted first before the other row of columns are installed. Practically, the tiang tuo indicates the limit of the front and back, the beginning and ending of the house [6].

Additionally, during building, the bundo kanduang (matriarch) will be given the honour to pull a rope tied to the column along with the community as a symbolic gesture to introduce the homeowners to the community. The influence demonstrates a strong matrilineal kinship in the ceremonial house. After the tiang tuo is erected, other columns are laid with the distance between columns at approximately five eto $(50 \mathrm{~cm})$ or 8 feet $[6,2]$. Side columns called tiang penegur/tiang tepi are columns that are supposed to greet guests before the guests enter the house. This is followed by the tiang tangah - the middle columns known as the eight columns symbolising the servers during ceremonies held in the house. The tiang panjang - the long column is also known as the unity column, the tallest among the columns; and the tiang tuo is among these long columns. The tiang dalam is located between the lanja bandua and a room known as the putri berkurung - the hidden princess, as the rooms can only be owned by women. The tiang salek is also known as the chastity column that protects the dignity of women in rooms away from prying eyes. These columns are installed with a five-degree slope. The structure is flexible and strong, able to withstand earthquakes that occur frequently. The stronger the tremors, the stronger the columns become.

The floor is mounted high, supported by tall columns (Fig. 15). The idea is to provide security to its residents and also preventing the residents from the threat of wild and poisonous animals, and avoiding the threat of floods that can occur at any time. In addition, this structure is also capable of channelling cool air under the house and into the house. The sun is also able to shine directly to the underneath of the house and can reduce the moisture that is trapped in the space, which can be used for other functions. The ceremonial houses are apparent in applying the construction system of mortise and tenon joint (Fig. 16). The creative community uses the universe as a guide. They use resources that are available to make a perfect house without the use of modern materials. Such a system would result in the construction of the building structure that is flexible in the event of an earthquake. The wall structure is one of the key elements in the house. The analogy is that the human body is viewed as a wall that is beautifully decorated with accessories, decorated with carvings of various means according to its functions. An important requirement inherent in the house's wall is the numbers of openings in the front and reduced at the back. The purpose of these windows is to create natural ventilation to provide fresh and cool air in the house. Bedrooms have no windows to avoid any intrusion into the room through the windows. However, the walls are made of bamboo that can provide natural ventilation to compensate the lack of windows (Fig. 17). 
322 Azizi Bahauddin, et al., Int. J. of Design \& Nature and Ecodynamics. Vol. 8, No. 4 (2013)

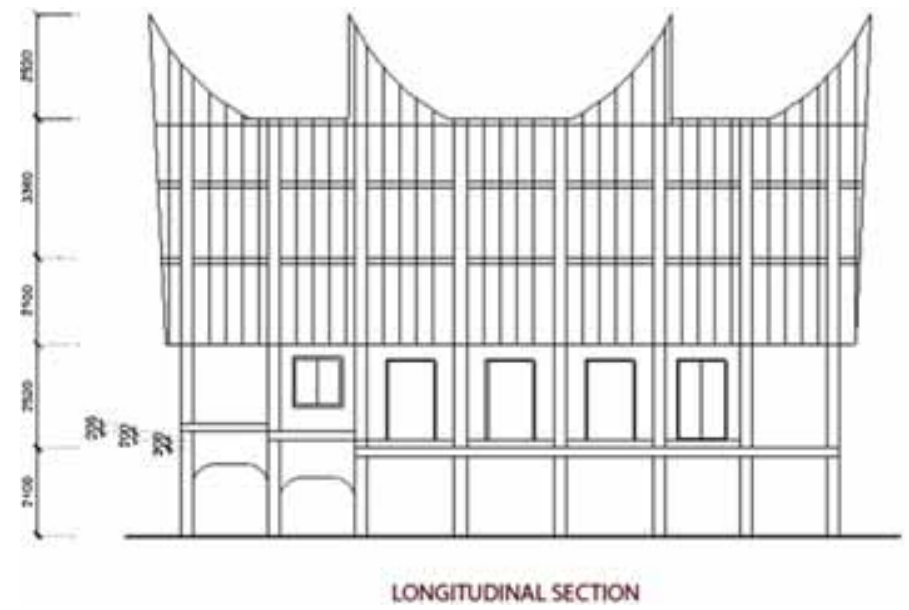

Figure 15: Longitudinal section with column positions.

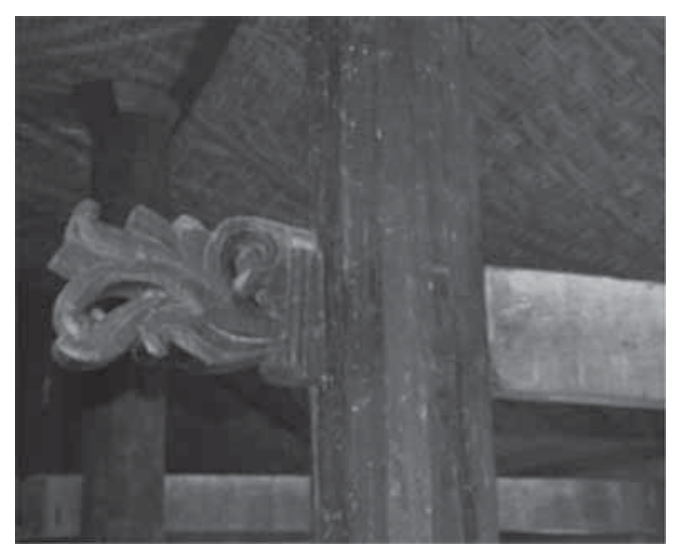

Figure 16: Construction systems similar to mortise and tenon joint.

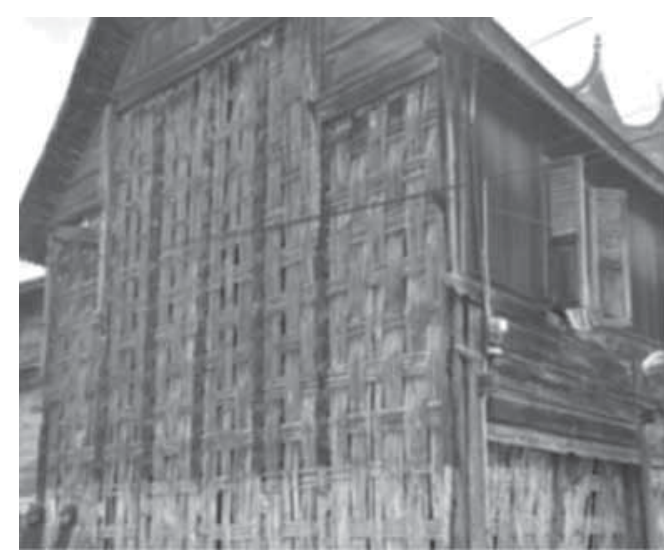

Figure 17: Bamboo wall. 


\section{CONCLUSIONS}

In Western Sumatera, the differences in the Minangkabau house design with and without verandas of different levels are caused by the differences in the governance of the customary systems of Bodi Caniago and Koto Piliang. However, the matrilineal influence on the architecture is very apparent. The womenfolk are the main beneficiaries and residents inhabiting the house as well as the authorities that have the right to design a home formed in a unique way. Even the men are given small roles during a ceremony celebrating. Architectural elements in the ceremonial house are a reflection of the culture and customs of the matrilineal society that need to be acknowledged by the unique culture of the Minangkabau society. The strength of the matrilineal influence can be seen in the layout of the interior, as space design is dominated and controlled by the women. Spaces for the young, older, unmarried, newly married, and 'have been married' women are adequately provided. The architectural features and design of the Minangkabau house can have an impact on sustainable design that fit the culture and natural environment. These can be observed from the application of local materials for house construction. They are renewable and easily planted without damaging the environment. Above all, these materials seem to intertwine with the beliefs in the attention given that the resources carry deeper meaning than just providing architectural components. This commitment sustains the cultural beliefs for generation. The issue of sustainability can be only seen in the beliefs, philosophies and rituals alone as well as the comfort provided for the house occupants through using natural materials. However, less can be determined in the reduction of energy and resources used. Ultimately, the layout of the space is consistently creating spaces to provide harmonious social relations, involving the lives of individuals, families and communities towards the environment. Such appearances of design can provide comfort and harmony to the occupants living with nature.

\section{REFERENCES}

[1] Fox, J. J., Comparative perspectives on austronesian houses: an introductory essay. Inside Austronesian Houses, Perspectives On Domestic Designs by Living, pp. 1-29, 1993.

[2] Idrus, Y., Rumah Tradisional Negeri Sembilan: Satu Analisis Seni Bina Melayu. Shah Alam: Fajar Bakti, pp. 1-3, 5-9, 116-129, 1996.

[3] Bahauddin, A., The traditional malay melaka house of malaysia: The Architectural and Cultural Heritage in Kazimee, B.A. Heritage and Sustainability in the Islamic Bulit Environment, pp. 93-110, 2012.

[4] Ahmad, A. G., Pemuliharaan Bangunan Warisan di Malaysia: Pengalaman dan Cabaran Masa Hadapan. Penang: Universiti Sains Malaysia, pp. 1-4, 2010.

[5] Asri, S., Prinsip-Prinsip Pembinaan Rumah Adat Minangkabau. Tesis PhD, Universiti Teknologi Malaysia, pp. 42-53, 59-61, 89-90, 2004.

[6] Is, S., Kajian Nilai-Nilai Budaya Pada Ekspresi Tata Ruang Dalam Rumah Adat Minangkabau: Kes Kajian Luhak Tanah Datar Sumatera Barat. Tesis PhD, Universiti Teknologi Malaysia, Johor, pp. 1, 4-5, 42-44, 66, 84-87, 105, 131-132, 136-147, 180, 182, 185-186, 2000.

[7] Jayatri, A., Rencana Induk Lanskap Kawasan Wisata Budaya Kompleks Istana Pagaruyung, Sumatera Barat. Tesis Sarjana, Institut Pertanian Bogor, Bandung, pp. 25-29, 2001.

[8] Widya, D., Kajian Arsitektur Rumah Tinggal Tradisional Minangkabau Nagari Panyalaian Kabupaten Tanah Datar. Tesis Sarjana, Universitas Diponegoro, Semarang, pp. 2, 30-31, 42-50, 2001.

[9] Soeroto, M., Pustaka Budaya \& Arsitektur. Jakarta: Myrtle Publishing, pp. 1-4, 21, 34, 2005.

[10] Kamaruzzaman. Budaya Alam Minangkabau: Falsafah \& Arsitektur Istano Basa Pagaruyung Serta Objek Wisata Lainnya. Tanah Datar, pp. 1-4, 2012.

[11] Hamka, Islam dan Adat Minangkabau. Shah Alam: Pustaka Dini, pp. 7-17, 161-171, 2006. 
[12] Abidin, M. J., Tinjauan Tentang Nilai-nilai Dasar Adat Minangkabau. Retrieved on July 7 , 2012, available at http://dokumentasibuya. blogspot.com /2010/12/tinjauan-tentang-nilainilai-dasar-adat.html. December 19, 2010.

[13] Nasroen, M., Dasar Falsafah Adat Minangkabau. Jakarta: Bulan Bintang, pp. 23, 25-26, 33, 44-45, 1957.

[14] Ng, C., Raising The House Post and Feeding The Husband-Givers. Inside Austronesian Houses, Perspectives On Domestic Designs by Living, pp. 121-143, 1980.

[15] Ibrahim, N., Adat Perpatih: Perbezaan Dan Persamaannya Dengan Adat Temenggung. Kuala Lumpur: Fajar Bakti, pp. 38, 45, 109, 1993.

[16] Edison \& Nasrun., Tambo Minangkabau: Budaya Dan Hukum Adat Di Minangkabau. Bukit Tinggi, Sumatera Barat: Kristal Multimedia, p. 2, 2010.

[17] Sidek, M. N., Rekabentuk Penyelidikan: Falsafah, Teori dan Praktis. Serdang: Universiti Putra Malaysia, 2002.

[18] Mat, N., Ciri-Ciri Fizikal Ruang Dalaman Rumah Melayu: Kajian Kes Rumah Bumbung Melayu Perak. Tesis PhD, Universiti Sains Malaysia, Penang, 2000.

[19] Manggis, R., Minangkabau, Sejarah Ringkas dan Adatnya. Jakarta: Mutiara, p. 40, 1971.

[20] Amir, M. S., Adat Minangkabau: Pola Dan Tujuan Hidup Orang Minang. Jakarta: Citra Harta Prima, pp. 1-7, 9, 1997.

[21] Gilbert, K., Living contradictions. The Women's Review of Books, 20(1), pp. 25-26, 2002. doi: http://dx.doi.org/10.2307/4024022

[22] Hermayulis, Peranan dan Kedudukan Perempuan Melayu dalam Masyarakat Matrilineal Minangkabau di Sumatera Barat. Sari, pp. 79-90, 2008.

[23] Selat, N., Sistem Sosial Adat Perpatih. Kuala Lumpur: Utusan Melayu (M) Berhad, pp. 29-52, 120-124, 1975.

[24] Azwar, W., Matrilokal dan Status Perempuan Dalam Tradisi Bajapuik. Yogyakarta: Galang Press, p. 31, 2001.

[25] Astuti, F., \& Soedarsono, R., Perempuan dalam seni pertunjukan minangkabau: Suatu tinjauan gender. Akademika Jurnal Kebudayaan, 4(1), ISSN: 0216-8219, pp. 32-40, 2006.

[26] Erman, M., Boestami, Moechtar, M. S., Zaiful, A., \& Nusjirwan, A., Rumah Gadang Minangkabau. Sumatera Barat: Proyek Pengembangan Permuseuman Sumatera Barat, p. 2, 1981.

[27] Yovita, W., Budaya Matrilineal Masyarakat Minangkabau Pada Arsitektur Rumah Gadang. Retrieved on February 14, 2012, available at http://www.scribd.com/doc/46656529/BudayaMatrilineal-Masyarakat-Minangkabau-pada-Arsitektur-Minangkabau, 2012 